\title{
Samen beslissen in de zorg
}

\section{Beter samenwerken, ook als dat lastig lijkt}

\author{
Bas Sorgdrager
}

Samen beslissen over functie- of arbeidsgeschiktheid? Welke bedrijfs- of verzekeringsarts doet dat in de spreekkamer met de cliënt? Empathie en vertrouwen of uitgaan van wantrouwen en zelfstandig oordelen? Hoe verloopt een spannend spreekuur en hoe zorg je ervoor dat het resultaat van het spreekuur bevredigend is? Hoe ga je om met de verschillende persoonlijkheidskenmerken die zich op het spreekuur aandienen?

Het boekje, kort en krachtig geschreven door een psychiater-psychotherapeut, levert nuttige achtergrondkennis en tips voor een effectieve samenwerking in de spreekkamer. Eén van de boodschappen: Een goed lopend spreekuur draagt bij aan het werkplezier van de professional.

Het boekje is in principe geschreven voor iedere zorgprofessional. Op de balans tussen professionele betrokkenheid en -distantie gaat het boekje minder in. Voor de bedrijfs- of verzekeringsarts die zich vooral prettig voelt bij enige distantie is de tip: Baseer uw handelen op gezag en niet op macht.

Bedrijfsartsen Henriet Smits en Peter Coffeng zijn betrokken bij concepten van het praktische handboek. Inhoudelijk is er aandacht voor veel voorkomende lastige psychiatrie en persoonlijkheidsstoornissen. En er is ook een hoofdstukje over de 'capability benadering'. Wat vindt iemand belangrijk in zijn werk, krijgt hij de mogelijkheid dit te realiseren en lukt dat ook?

Ieder mens wil zich gehoord en gezien voelen, serieus genomen worden. Specifieke aandachtspunten worden benoemd, zoals de waarde van handelen op gezag en niet op macht en het betrekken van naasten bij complexe of belastende situaties. In de bijlage staat een checklist voor een succesvol spreekuur. Het boekje biedt noodzakelijk inzicht in de achtergronden van gedrag van de cliënt en

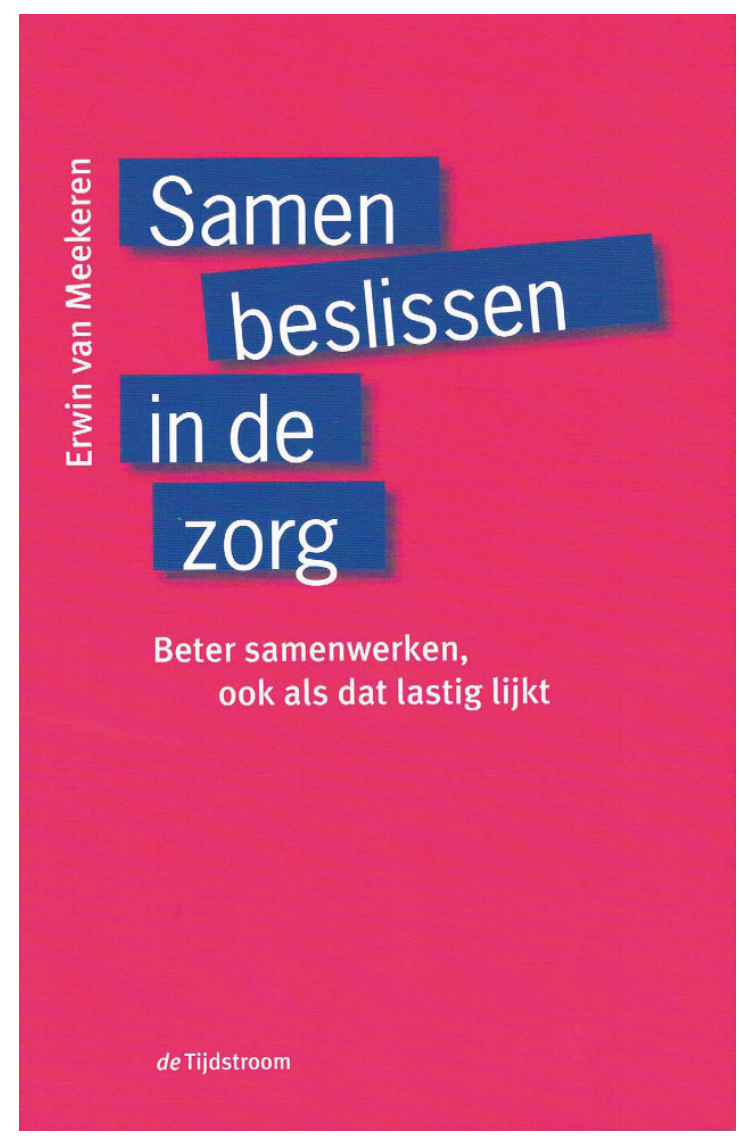

de reactie erop van de professional. De zelfevaluatie in de bijlage is hiervoor een nuttig zelfreflectie instrument. Samen beslissen in de zorg is een handig naslagwerk in situaties wanneer het lastig wordt.

Samen beslissen in de zorg; beter samenwerken, ook als dat lastig lijkt.

Erwin van Meekeren. Uitgeverij De Tijdstroom, 2018. ISBN 9789058980922, 138 pagina's, € 24,-. 